\title{
A Stylistic Study of English Catholic Death Prayers
}

\author{
DR. Riyadh.Tareq Al-Ameedi, University of Babylon, College of Education for Human Sciences, Department of \\ English, hum.riyadh.tareq@uobabylon.edu.iq \\ Masoumah Abathar Witwi, University of Babylon, College of Education for Human Sciences, Department of \\ English,V78bnkbffe@gmail.com
}

\begin{abstract}
Death from a phenomenological point of view is non- being. Death is the opposite of life in that life's nature deals with activity, aims and making order from disorder. Death is non-life and inactive. Although death is the state of a stillness, it is a huge chaos. In contrast to life which has an active meaning, death is separated from any type of meaning and value.This paper investigates stylistic devices used in a number of catholic death prayers. This paper deals with death prayers that are found in the selected English texts. This paper aims at finding out the effect of death or preparation for death in Catholic traditions. It is based on Leech and Short's (1981) for analyzing the selected texts on phonological, lexical, and syntactic levels. According to this model, it also analyzes the tropes that are used in these texts.
\end{abstract}

Keywords: study, players, death.

Received: 08.12.2020

Accepted: 10.01 .2021

Published: 03.02.2021

\section{Introduction}

The present study investigates death prayers and the stylistic choices that are made in the catholic death prayers which contain a number of catholic death prayers that are said in the time of death or after death. Stylistic choices that are behind the complexity and eloquence of death prayers have not been investigated in a stylistic study. This study tries to answer the following questions: 1- What are the figures of speech used on the phonological, lexical, and grammatical levels in the Catholic death prayers? 2- What are the tropes that are used in such prayers? The aim of the present study: 1- is to investigate the use of stylistic devices on phonological, lexical, syntactic levels, and the tropes used in both texts. The current study hypothesizes the followings: the Catholic death prayers text uses alliteration and assonance on the phonological level, anaphora, epistrophe, polyptoton, tautology on the lexical level, asyndeton, hypotaxis , inversion, parallelism , parataxis , polysyndeton on the syntactic level, and finally apostrophe , metaphor and personification tropes are used in this text.

\section{Stylistics}

Wales (2011: 399) states that stylistics is the study of style and as the style can be viewed in different ways, so there are different approaches to stylistics. The verification in the field of stylistics is related mainly to the influences of different linguistic branches on the field of stylistics. Tariq (2018:46-50) explains that stylistics deals with the study of language and the relationship of language to literature. Stylistics is considered as one of the moderate approaches to literature. Leech and Short (2007:11) explain that stylistics is the linguistic study of style and it is rarely undertaken for itself. The linguist deals with style because he wants to understand something or explain something. Literary stylistics is in general designed to express the relation of language to the artistic work. The questions that are asked within stylistics are not so much why, how, and what but the question of why the author chooses this form of expression rather than another one. Stylistics aims to relate the aesthetic nature of artistic work that is related to the literary criticism to the linguistic choices that are related to linguistics. The relationship between the two is a cyclic one since the aesthetic nature of the literary work and the linguistic nature of the linguistic field do motivate each other continually. Leech and Short (2007: 100) explain how the analysis of literary texts can be done using the differences between the real world of reality and the mock reality. They think that the mock reality depends on the realworld reality for its interpretation. They propose a figure which can be applied to the analysis of style. They focus on the stylistic variation as a choice and state that the analysis can be done on three linguistic levels: semantic, syntactic, and graphological( Bustan \&Alakrash 2020, Bustan \& Alakrash 2020, Alakrash et.al.2020, Elaf \& Alakrash 2020 ). 


\section{Death Prayers}

Oxford English Dictionary (2020) defines 'praying' as speaking to a God either privately or in a religious ceremony to express love, admiration, or thanks or to ask for something. Merriam Webster's Dictionary (2020) defines 'prying' as addressing God or a god with adoration, confession, supplication, or thanksgiving.

The American Heritage Student Dictionary (2003: 256) defines death as the act of dying, the end of life. The condition of being dead. Emery (2016: 1) states that death is around us and it is a certain aspect of life and touches each of us. In the end, we all face death as part of fate. Emery (2016: 1) defines death as the unavoidable end of all human life. Man is destined to dye from the moment of birth. Death is not something that happens instantly but comes gradually. There are initial stages to death gradually leading to the final stage.

According to Christianity, death represents life after death and the doorstep to the endless eternal life, and individuals are prepared to live a life in God's presence. For people who are considered believers, death is not something to fear or worry about. Here, death is considered as an enemy and it is not part of God's original design for human beings and the concept of death regarding dignity is an oxymoron since death means that sin is an eternal one and cannot be removed (Raee and Cox,1999:229).

Regarding praying for death, Christian people must be compassionate toward someone who is dying which is the best feature a person can have when he is near to somebody who is dying. Christian ethics considers the importance of patience in such situations and gives hope and patience to the person who is dying. Christian ethics understands and is aware that pain should be minimized in the time of death. The physical suffering can be minimized but the spiritual suffering of the near-death, parting those whom we love, and losing life cannot be eliminated (Vogt, 2004: 54).

\section{Catholic Death Prayers}

These prayers are recited with the dying person and they are often repeated several times. Also, the dying person can be signed by a cross on his forehead just as was done in the time of Baptism (Catholic Prayers for Death and Dying: Catholic Diocese of Pittsburgh).

\section{Methodology}

The method that is used in the present study is a qualitative one. The model in this study is confined to is Leech and Short's (1981: 75-80). This model consists of the following :(C. Figures of Speech 1) grammatical and lexical schemes; 2) phonological schemes; 3) tropes).

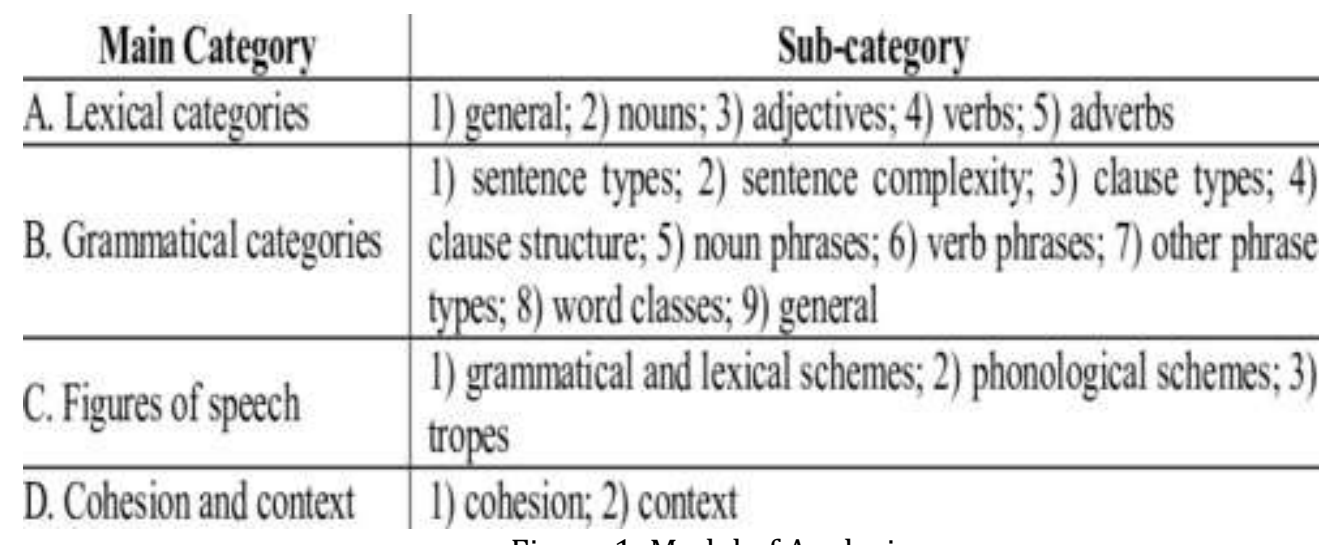

Figure 1: Model of Analysis

The sample of the analysis is the English prayers (Catholic Death Prayers). Regarding the English death prayer (Catholic Death Prayers), several short supplications before death are analyzed.

\section{Data Analysis and Results}

In this section, the selected Catholic Death prayers are going to be analyzed. These texts are short texts and Scripture Readings. Scripture Reading consists of (John 6:37-40), Psalm 23, Psalm 91, and Psalm 121. 


\section{Phonological Level \\ Alliteration}

The selected death prayers that are going to be analyzed on the phonological level are short texts, John 6:3740, Psalm 23, Psalm 91, Psalm 121, and prayer of commendation.

Whether we live or die, we are the Lord's (Rom 14: 8).

We shall always be with the Lord. (1 Thes 4:17).

Alliteration is used here to emphasize that we are all destined to die.

Though I should walk in the valley of the shadow of death (Ps 25:1).

This device is used here to focus on the idea of approaching death.

In green pastures he makes me lie down;

To still waters he leads me;

He restores my soul

He guides me along right paths

For the sake of his name (Psalm 23).

Alliteration is used here to shed light on God's mercy toward the dying Christian and that he is going to be in peace.

Go forth, faithful Christian

This device is used here to help the dying Christian to die peacefully.

\section{Assonance}

Wales $(2018: 35)$ states that this device is a part of language sound pattering, a half rhyme and is common in poetic language. Using this device, the same stressed vowel is repeated in words but with different consonants.

I will deliver him and give him honor

With length of days I will satisfy him

And fill him with my saving power (Psalm 91).

This device is used here to show's God' mercy toward the dying Christian.

\section{Lexical Level}

Anaphora

Wales (2018: 20) explains that anaphora is a very common figure used in speech and deals with the repetition of the same words at the beginning of several successive clauses or sentences. This device is used in verse and prose for showing the descriptive and emotional effects.

Everything that the Father gives me will come to me, and I will not reject anyone who comes to me, because I came down from the heaven not to do my own will but the will of the one who sent me and this is the will of the one who sent me (John: 6: 37-40).

Anaphora is used here to shed light on the fact that death is acceptable by the dying Christian and he accepts his faith.

The Lord is your guardian

The Lord is your shade (Psalm 91).

This device is used here to show that God will help the dying Christian after his death and God will protect him.

The Lord will guard you against the evil;

He will guard your soul

The Lord will guard your coming and going (Psalm 121).

This device is you here to emphasize that God protects those who believe in him.

In the name of Jesus Christ, Son of the living God

Who suffered for you

In the name of the wholly Spirit (Prayer of Commendation).

Anaphora is used here for the dying Christian to repeat God's name before the moment of his death. 


\section{Epistrophe}

Wales (2018: 141) explains epistrophe as a device for repetition and it is the opposite of anaphora. The last word in successive lines, clauses, or phrases are repeated.

To still waters he leads me

I will fear no evil, for you are with me;

Your rod and Your staff comfort me.

You set a table before me (Psalm 23).

This device is used to shed light on the graces of God that will surround the dying Christian after his death, so he is not afraid.

\section{Polyptoton}

This device refers to the repetition of the words in different case forms when the words repeated are derived from the same root as in the cases of conversion or affixation.

The LORD is your guardian

The LORD will guard you against all evil (Psalm 121).

This device is used here to show that God will protect the dying Christian so he is protected by God because he believes in him.

\section{Tautology}

As was stated before, this device means saying the same thing twice so that part of the sentence is redundant. The words that are used can be developed and expanded and it is the repetition or the duplication of words (Al- Marsumi, 2017: 1).

In to your hands I commend my spirit (Ps 31:6a).

To you, O LORD, I lift up my soul. (Ps 25:1).

We shall always be with the lord's. (Rom 14:8).

Lord Jesus, receive my spirit (Acts $7: 59$ ).

This device is used to shed light on the moment of death of the dying Christian and ask God to welcome his soul.

To still waters he leads me;

I will fear no evil, for you are with me

Your rod and Your staff comfort me (Psalm 23).

You who dwell in the shelter of the highest,

Who abides in the shades of the Almighty, (Psalm 91).

The dying Christian is under God's protection and mercy, so he can be relieved when he knows that God will protect him after his death.

Indeed, goodness and mercy will pursue me

All the days of my life;

I will dwell in the house of the LORD

For endless days (Psalm 23).

This device is used here to show that the dying Christian is leaving now to his eternal life that starts immediately after his death.

Say to the Lord " My refuge and fortress,

And under his wings you may take refuge

Because you have the LORD for your refuge

To guard you whenever you go.

With their hands they shall support (Psalm 91).

The LORD is your guardian;

The LORD is your shade

The LORD will guard you from the evil;

He will guard your soul.

The LORD will guard your coming and going (Psalm 121). 
Tautology is used here to comfort the dying Christian about what happens after his death and he will be protected by God and His angles.

\section{Sentential Level}

\section{Asyndeton}

This device refers to coordinated clauses or phrases without the existence of any explicit conjunctions or connectives, Wales (2011: 36).

You set a table before me

in front of my enemies;

You anoint my head with oil;

My cup overflows (Psalm 23).

Behold, the guardian of Israel

never slumbers nor sleeps

The LORD is your guardian;

The LORD is your shade

At your right hand (Psalm 121).

This device sheds light on the blessings of God on the dying Christian and how God will take care of him and keep him from any danger.

\section{Hypotaxis}

Hypotaxis is called subordination of clauses. It refers to the dependent clause that is related to the main clause by conjunction, (Wales 2011: 204).

Everything that the Father gives me will come to me, and I will not reject anyone who comes to me, because I come down from heaven, not to my own will but the will of the one who sent me. And this is the will of the one who sent me, that I should not lose anything of what he gave me, but that I should raise on the last day. For this is the will of my father, that everyone who sees the son and believes in him may have eternal life, and I shall raise him on the last day (John $6: 37: 40$ ).

This device is used here to present the notion that the dying Christian accepts his destiny and ready to start his eternal life that follows death.

\section{Inversion}

Wales (2018: 239) states that inversion is known as hyperbaton and the most common type of inversion is the inversion of subject and verb.

Though I should walk in the valley of death, no evil would I fear, for you are with me. (Ps 23: 4).

This device is used here to show that the dying Christian shall not be afraid after death since God is protecting him.

In to your hands, I commend my spirit. (Ps 31: 6a).

In green pastures he makes me lie down (Psalm 23).

The purpose here is that the dying Christian will be at comfort after his death so one can die peacefully.

And under his wings, you may take refuge (Psalm 91).

Near you, it shall not come (Psalm 91).

And have made the Highest your stronghold (Psalm 91)

No evil shall befall you (Psalm 91).

With their hands they shall support you, (Psalm 91).

Because he clings to me I will deliver him;( Psalm 91).

Because he knows my name I will set him on high (Psalm 91).

By day the sun will not strike you

Nor the moon by night.

This device is used here to show that God will protect the dying Christian. The subordinate clause is fronted to show that the dying person will be under God's protection after his death and will not suffer since he believes in God.

The punishment of the wicked you will see (Psalm 91).

This device is used here to shed light on God's punishment. 


\section{Parallelism}

Parallelism is very common in rhetoric. It is the repetition of the same structural pattern often between phrases and clauses (Wales,2011: 301).

Holy Mary, pray for me. Saint Joseph, pray for me, Jesus, Mary and Joseph, assist me in my last agony.

He will rescue you from the fowler's snare,

He will shelter you with pinions (Psalm 91).

Though a thousand fall at your side

Ten thousand at your right hand (Psalm 91).

Behold, the guardian of Israel

Never slumber nor sleeps.

The LORD is your guardian

The LORD is your shade (Psalm 121).

This device shows that God will protect the dying Christian after his death.

Go forth, Christian soul, from this world

In the name of God, the almighty father,

Who created you

In the name of Jesus Christ, Son of the Loving God,

Who suffered for you

In the name of the Holy Spirit

Who was poured out upon you (Prayer of Commendation: As the time of death approaches)

This device repeats the name of God for the dying Christian before the moments of his death.

\section{Parataxis}

Wales (2018: 303) states that this device deals with linking clauses by depending on juxtaposition instead of using any type of subordination.

Whether we live or die, we are the lord. (Rom 14:8).

To you, O LORD, I lift my soul (Ps 25:1)

It views that all humans are destined to die.

The Lord is my shepherd;

there is nothing I lack (Psalm 23).

In green pastures he makes me lie down; (Psalm 23)

To still waters he leads me;( Psalm 23).

You set a table before me

In front of my enemies;

You anoit my head with oil;

My cup overflows (Psalm 23)

This device shows God's blessing on the dying Christian after his death.

\section{Polysyndeton}

Wales (2018: 330) defines this device rhetorically as the marked or especial use of a number of conjunctions in succession especially for the same conjunction and often for the coordinating clauses or phrases.

You Shall not fear the terror of the night

Nor the arrow that flies by day

Nor the pestilence that roams in darkness

Nor the plague that ravages at noon.

This device is used here to view that the dying Christian must not be afraid because God will prevent any suffering that can occur to him and he will live in heaven.

\section{Rhetorical Tropes: Apostrophe}

Apostrophe means turning away from the audience to address some other person, a dead person, The God, or an inanimate object as they are personified.

To you, O LORD, I lift my soul. (1 Thes 4:17). Lord Jesus, receive my spirit (Acts 7: 59). 
The apostrophe is used here to view the fact that the dying Christian is leaving to his second life after death and his soul will be delivered by God.

\author{
Metaphor \\ Bajwa (2017: 1) states that metaphor is to compare two unlike things and simile, personification, \\ anthropomorphism, hyperbole, parable, fable, and analogy are metaphors. \\ Though I should walk in the valley of the shadow of death, no evil would I fear, for you are with me (Ps \\ 23:4). \\ Metaphor is used here to view the approaching death.
}

\title{
Personification
}

Personification is a figure of speech where inanimate objects, non-human or anything abstract is given human features.

Though I should walk in the valley of the shadow of death, no evil would I fear, for you are with me (Ps 23:4).

Personification is utilized here to view death as a strong and fearful personal. The texts use alliteration on the phonological level, epistrophe, polyptoton, and tautology on the lexical level, asyndeton, hypotaxis, and parallelism on the sentential level, an apostrophe and personification tropes are used in these texts. The aim behind using alliteration and assonance on the phonological level is to help the dying Christian to die peacefully, and to show God's mercy toward the dying Christian. On the lexical level, anaphora is used to show God's help for the dying Christian, epistrophe shows God's grace, Polyptoton emphasizes God's protection, and tautology is used to show that the dying Christian is under God's protection and is leaving peacefully to the eternal life. On the sentential level, asyndeton is used to view God's blessing. Hypotaxis is used to show that the dying Christian is accepting his fate and moving to his eternal life. Inversion is used to show God's protection and shedding light on God's punishment. Parallelism is used to repeat the name of God before death, Parataxis is used to view that all humans are destined to die and polysyndeton is used here to comfort the dying Christian not to be afraid of death. Regarding rhetorical tropes, the Catholic death prayer text uses an apostrophe to view that all humans are destined to die. Personification and metaphor are used to view death as approaching like a very strong capable person.

\section{Conclusion}

There are different stylistic devices and deviations in Catholic death prayers that refer to the Christianity religion and its traditions. Catholic death prayer texts express the idea of the approaching death that must be accepted moving from this life that is described as being a passage to the eternal life after death. This text utilizes stylistic devices and rhetorical tropes on the phonological, lexical, and sentential levels to express the fact that there is no escape from death, God's mercy toward the dying Christian, God's protection and blessing in heaven for those who are believers, dying peacefully and safely, repeating God's name at the moment of death, God protects the dying Christian from any type of pain or harm and finally moving to eternal life.

\section{Bibliography}

Al- Marsumi , N. H. R. (2017). The Use of Tautology " The Thorn" by William Words Worth: A Stylistic Study. Arab World English Journal. AWEJ for Translation \& Literacy Studies Volume, 1 number 3, August 2017.

Alakrash, HM, Razak, NA, \& Bustan, ES (2020). The Effectiveness Of Employing Telegram Application

In Teaching Vocabulary: A Quasai Experimental Study. Multicultural Education, 6(1).

Bajwa, Z. (2017). Conceptual Metaphor Theory and Emotion Stylistics: An Analysis of Urdu Poems. MA thesis.

Department of Linguistics: Faculty of Social Sciences. Quaid-E-Azam University, Islamabad.

Bustan, E.S, Alakrash, H. M. (2020). Critical Discourse Analysis of Donald Trump's Tweets Addressing the Middle Eastern Countries.International Journal of Future Generation Communication and Networking,13(2), 26-38.

Bustan, E.S., Alakrash, H. M. (2020). Gender Analysis Amongst Male and Female Malaysian Travelling Bloggers. International Journal of Academic Research in Business and Social Sciences, 10(6), 1-9. 
Byock, I. (2002). The Meaning and Value of Death. Journal of Palliative Medicine. Volume 5, Number 2, 2002. Mary Ann Liebert, Inc.

Elaf, B.S, Alakrash, A.M. (2020). An analysis of impoliteness strategies performed by Donald Trump tweets addressing the middle east countries.Global journal of Social Science and Humanities,1, 66-74.

Emery, P. (2016). Death and Dying: A Christian Approach. Shelda L. Hudson. National Center of Continuing Education. Inc.

Leech, J. and Short, M. (2007). Style in Fiction: A Linguistic Introduction to English Fictional Prose. United Kingdom: Pearson Education

Pomorska, K. (Ed.). (1987). Language, Poetry and Poetics. Amsterdam: Mouton.

Rae,S.B and Cox, M. P. (1999). Bioethics: A Christian Approach in a Pluralistic Age. New York: Wm.B. Eerdmans Publishing Co.

Tariq, M. (2018). Style, Stylistics and Stylistic Analysis: A Re-evaluation of the Modern-day Rhetorics of Literary Discourse. International Journal of English Research. Volume 4; Issue 2; March 2018; 46-50

The American Heritage Student Dictionary (2003). Houghton Mifflin: Boston. New York.

Vogt, P. (2004). Patience, Compassion, Hope, and the Christian Art of Dying Well. Lanham: Rowman and Little Field Publishers, INC. Volume 5, Number 2. Page 1- 2.

Wales, K. (2018). A Dictionary of Stylistics. Third Edition. Routledge: London and New York. 